\title{
PENGEMBANGAN BAHAN AJAR MATA KULIAH PENULISAN KREATIF BERMUATAN NILAI-NILAI PENDIDIKAN KARAKTER RELIGIUS BAGI MAHASISWA PRODI PBSI, FKIP, UNISSULA
}

\author{
Meilan Arsanti \\ Email: meilanarsanti@unissula.ac.id
}

\begin{abstract}
Prodi Pendidikan Bahasa dan Sastra Indonesia, Fakultas Keguruan dan Ilmu Pendidikan, Universitas Islam Sultan Agung, Indonesia
\end{abstract}

\begin{abstract}
Abstrack
The availability of teaching materials in learning is very important. Teaching materials contains information related subjects that are taught as well as in subjects Creative Writing on Indonesian department, Faculty of Teacher Training and Education, University of Sultan Agung. The writer used $R \& D$ design in developing teaching materials that contain religious values in education. Based on the result of the study, the students needed instructional materials in the form of textbooks in accordance with the standard of textbook worthiness, which include (1) the feasibility of the content, (2) feasibility of presentation, (3) language feasibility, and (4) feasibility of chart. The characteristics of teaching materials were (1) self instructional, (2) self contained, (3) stand alone, (4) adaptive, and (5) user friendly. The prototype of Creative Writing material was entitled Exist and Religious which contains religious values. The teaching material consisted steps of writing poetry, short stories, drama texts, biographical texts, anecdotes, and stories such as fables, myths, legends, tales, etc. Based on the experts' validation, it was shown that the score was 86 with very good category and there were revision on the layout to show the religious value. It was supported by the result of independent sample $t$-test showed the value of $t$ obtained was 10,242 at significance level 0,000 and degree of freedom $(d f)=141$ with $95 \%$ confidence level. It can be concluded that Ho was accepted and there was significant difference between mean score before and after student creative writing by using Creative Writing material for t count $(10,242)>t$ table $(0,679)$. Therefore, the teaching materials were effective and accepted. Hopefully, the teaching materials in the form of textbooks allow students to learn about Creative Writing and can explore their writing skills.
\end{abstract}

keywords: teaching material, religious value, creative writing

\section{Abstrak}

\begin{abstract}
Ketersediaan bahan ajar dalam pembelajaran mutlak diperlukan. Hal tersebut karena dalam bahan ajar terdapat informasi terkait mata kuliah yang dilaksanakan seperti halnya pada mata kuliah Penulisan Kreatif pada Prodi Pendidikan Bahasa dan Sastra Indonesia, FKIP, Unissula. Belum adanya bahan ajar khusus untuk mata kuliah tersebut melatarbelakangi penelitian $R \& D$ ini untuk mengembangkan bahan ajar Penulisan Kreatif yang bermuatan nilai-nilai pendidikan karakter religius. Dari hasil analisis kebutuhan diketahui bahwa mahasiswa membutuhkan bahan ajar berupa buku teks yang sesuai dengan standar kelayakan buku teks yang meliputi (1) kelayakan isi materi, (2) kelayakan penyajian, (3) kelayakan kebahasaan, dan (4) kelayakan kegrafikaan. Adapun karakteristik bahan ajar tersebut, yaitu (1) self instructional, (2) self contained, (3) stand alone, (4) adaptive, dan (5) user friendly. Prototipe pengembangan bahan ajar Penulisan Kreatif berjudul Eksis dan Religius dengan Menulis Kreatif yang berisi tentang nilai religius dalam sebuah tulisan dan panduan atau langkah-langkah penulisan puisi, cerpen, naskah drama, teks biografi, anekdot, dan cerita seperti fabel, mite, legenda, dongeng, dll. Dari hasil uji validasi prototipe oleh ahli diperoleh skor 86 dengan kategori sangat baik walaupun ada sedikit revisi pada bagian layout agar lebih menonjolkan sisi religius sesuai dengan judul yang dipilih. Berdasarkan Uji-t diketahui t sebesar 10,242 dengan tingkat signifikansi (sig) sebesar 0,000 dan derajat kebebasan $(d f)=141$ dengan taraf kepercayaan 95\% yang dapat disimpulkan bahwa Ho diterima dan terdapat perbedaan yang signifikan antara rata-rata nilai mahasiswa sebelum dan sesudah belajar menulis kreatif dengan menggunakan bahan ajar Penulisan Kreatif karena t hitung $(10,242)>t$ tabel $(0,679)$. Oleh karena itu, bahan ajar tersebut efektif dan diterima. Harapannya dengan adanya bahan ajar berupa buku teks tersebut memudahkan mahasiswa dalam mempelajari tentang Penulisan Kreatif dan dapat menggali keterampilan menulis mereka.
\end{abstract}

kata Kunci: bahan ajar, nilai karakter religius, penulisan kreatif

\section{PENDAHULUAN}

Bahan ajar merupakan salah satu faktor penting dalam keefektifan sebuah pembelajaran terlebih di tingkat Perguruan Tinggi. Kurangnya bahan ajar tentunya dapat memengaruhi kualitas pembelajaran atau perkuliahan. Dalam buku Pedoman Penulisan Buku Pelajaran (Depdiknas 2005:3) disebutkan bahwa "yang termasuk isi pendidikan ialah segala sesuatu yang oleh pendidik langsung diberikan kepada 
peserta didik dan diharapkan untuk dikuasai peserta didik dalam rangka untuk mencapai suatu kompetensi tertentu dalam pendidikan." Dalam konteks pendidikan di Perguruan Tinggi, khususnya pada mata kuliah Penulisan Kreatif, dosen yang memberikan informasi dari bahan ajar yang digunakan kepada mahasiswa melalui proses perkuliahan. Dari informasi yang diberikan dosen tersebut diharapkan mahasiswa mengembangkannya di luar perkuliahan.

Faktanya bahan ajar yang tersedia saat ini belum sesuai dengan kebutuhan. Misalnya pada Prodi Pendidikan Bahasa dan Sastra Indonesia, FKIP, Unissula bahkan saat ini belum ada bahan ajar khusus tentang Penulisan Kreatif padahal mata kuliah tersebut tercantum pada kurikulum yang digunakan. Hal itu tentunya memengaruhi keefektifan perkuliahan mata kuliah tersebut. Dalam memenuhi kebutuhan bahan ajar tersebut dosen harus menyediakan sendiri sesuai dengan karakteristik mahasiswa dan mata kuliah yang diampu. Adapun karakteristik bahan ajar yang baik menurut Depdiknas (2004) adalah substansi materi diakumulasi dari standar kompetensi atau kompetensi dasar yang tertuang dalam kurikulum, mudah dipahami, memiliki daya tarik, dan mudah dibaca. Selain itu, dalam menyediakan bahan ajar dosen juga harus mempertimbangkan kriteriakriteria yang meliputi (1) relevansi (secara psikologis dan sosiologis), (2) kompleksitas, (3) rasional/ilmiah, (4) fungsional, (5) ke-up to date-an, dan (6) komprehensif/keseimbangan (Tim Pengembang MKDP Kurikulum dan Pembelajaran UPI
2011:152). Semetara itu, berdasarkan kriteria penilaian bahan ajar berupa buku pelajaran setidaknya ada empat syarat terpenuhi bila sebuah bahan ajar dikatakan baik, yaitu (1) cakupan materi atau isi sesuai dengan kurikulum, (2) penyajian materi memenuhi prinsip belajar, (3) bahasa dan keterbacaan baik, dan (4) format buku atau grafika menarik (Puskurbuk 2012).

Mata kuliah Penulisan Kreatif diberikan kepada mahasiswa Prodi Pendidikan Bahasa dan Sastra Indonesia dengan tujuan untuk memberikan keterampilan menulis pada bidang sastra, misalnya menulis puisi, cerpen, novel, drama, anekdot, legenda, mite, dan lain-lain. Selain itu, mata kuliah tersebut juga bertujuan untuk menampung dan menumbuhkan minat mahasiswa dalam bidang penulisan kreatif sastra. Tidak hanya itu, melalui mata kuliah tersebut mahasiswa juga dapat mengasah kemampuan mereka dalam bidang penulisan kreatif hingga mampu menulis berbagai jenis karya kreatif. Dengan keterampilan tersebut selanjutnya diharapkan dapat menjadi salah satu kecakapan hidup (life skill) yang dimiliki mahasiswa yang dapat bermanfaat ketika sudah lulus dan menginjak dunia kerja. Kecakapan hidup tersebut antara lain yaitu kecakapan sebagai penulis profesional. Sebenarnya bidang penulisan kreatif bersifat luas dan tidak hanya menyangkut sastra saja, tetapi juga nonsastra dan tidak hanya fiksi, tetapi juga nonfiksi.

Produk akhir dari mata kuliah ini adalah mahasiswa membuat antologi karya mereka baik puisi, cerpen, drama, anekdot, legenda, dan lainlain. Pada intinya adalah pendokumentasian karya mahasiswa 
dalam bentuk buku. Harapannya pada mata kuliah ini mahasiswa tidak hanya mengerjakan tugas, tetapi mengerjakan secara serius untuk menghasilkan karya yang luar biasa. Tentunya hal tersebut menjadi sebuah pengalaman dan kebanggan tersendiri atas karya mereka. Hal tersebut tidak hanya menguntungkan bagi mahasiswa, tetapi juga bagi prodi karena dapat digunakan untuk penambahan nilai pada saat akreditasi.

Agar perkuliahan Penulisan Kreatif dapat terlaksana secara efektif dan mencapai tujuannya maka diperlukan sarana pendukung berupa bahan ajar yang berkualitas dan dapat memudahkan mahasiswa dalam belajar menulis kreatif pada Prodi Pendidikan Bahasa dan Sastra Indonesia, FKIP, Unissula. Selama ini mata kuliah Penulisan Kreatif dilaksanakan dengan menggunakan bahan ajar seadanya baik dari bukubuku atau referensi yang tersedia di toko buku maupun referensi dari internet. Namun, bahan ajar atau referensi yang digunakan selama ini masih jauh dari nilai-nilai religius apalagi referensi yang diunduh dari internet. Oleh karena itu, pengembangan bahan ajar Penulisan Kreatif bermuatan nilai-nilai pendidikan karakter religius bagi mahasiswa Prodi Pendidikan Bahasa dan Sastra Indonesia (PBSI), FKIP, Unissula dilakukan.

Sesuai dengan rumusan masalah, maka penelitian ini dilakukan dengan tujuan untuk 1) merumuskan kebutuhan pengembangan bahan ajar mata kuliah Penulisan Kreatif bermuatan nilai-nilai pendidikan karakter religius bagi mahasiswa Prodi Pendidikan Bahasa dan Sastra Indonesia, FKIP, Unissula, 2) merumuskan karakteristik bahan ajar mata kuliah Penulisan Kreatif bermuatan nilai-nilai pendidikan karakter religius bagi mahasiswa Prodi Pendidikan Bahasa dan Sastra Indonesia, FKIP, Unissula, 3) mengembangkan prototipe bahan ajar mata kuliah Penulisan Kreatif bermuatan nilai-nilai pendidikan karakter religius bagi mahasiswa Prodi Pendidikan Bahasa dan Sastra Indonesia, FKIP, Unissula, dan 4) mengetahui keefektifan bahan ajar mata kuliah Penulisan Kreatif bermuatan nilai-nilai pendidikan karakter religius bagi mahasiswa Prodi Pendidikan Bahasa dan Sastra Indonesia, FKIP, Unissula. Dengan demikian, setelah dilakukan penelitian ini peneliti dapat mengetahui kebutuhan dan karakteristik yang selanjutnya dikembangkan menjadi prototipe bahan ajar mata kuliah Penulisan Kreatif bermuatan nilai-nilai pendidikan karakter religius bagi mahasiswa Prodi Pendidikan Bahasa dan Sastra Indonesia, FKIP, Unissula.

\section{KAJIAN TEORI}

\section{Bahan Ajar}

Salah satu tugas utama pendidik atau dosen pada tingkat Perguruan Tinggi yaitu merencanakan perkuliahan. Tugas perencanaan pembelajaran atau perkuliahan tersebut meliputi a) merumuskan tujuan instruksional; b) menyusun bahan kajian/Garis Besar Program Perkuliahan (GBPP); b) membuat Rencana Kegiatan Pembelajaran Semester (RKPS) atau Satuan Acara Perkuliahan (SAP); c) menyusun kontrak perkuliahan; dan d) menyusun buku ajar. Adapun 
pengertian bahan ajar yang dikemukakan Depdiknas (2006b:1) yaitu bahan ajar adalah segala bentuk bahan yang digunakan untuk membantu guru/instruktur dalam melaksanakan kegiatan belajar mengajar di kelas, baik berupa bahan tertulis seperti hand out, buku, modul, lembar kerja mahasiswa, brosur, leaflet, wallchart, maupun bahan tidak tertulis seperti video/film, VCD, radio, kaset, $\mathrm{CD}$ interaktif berbasis komputer dan internet. Bahan ajar dalam bentuk tertulis berupa materi yang harus dipelajari mahasiswa sebagai sarana untuk mencapai standar kompetensi dan kompetensi dasar. Materi pembelajaran tersebut berupa pengetahuan, keterampilan, dan sikap yang harus diajarkan oleh pendidik dan harus dipelajari oleh mahasiswa untuk mencapai standar kompetensi dan kompetensi dasar. Secara terperinci, jenis-jenis materi ajar terdiri dari pengetahuan (fakta, konsep, prinsip, prosedur) keterampilan, dan sikap atau nilai.

Dengan demikian, dapat disimpulkan bahwa bahan ajar memiliki peran yang sangat penting dalam keefektifan pembelajaran di Perguruan Tinggi. Dalam proses perencanaan pembelajaran tersebut dosen bertugas untuk menyiapkan bahan ajar yang dapat menunjang proses pembelajaran, sehingga dapat membantu mahasiswa dalam mencapai tujuan pembelajaran secara optimal. Bahan ajar tersebut dapat berupa tertulis seperti hand out, buku, modul, lembar kerja mahasiswa, brosur, leaflet, wallchart, maupun bahan tidak tertulis seperti video/film, VCD, radio, kaset, $\mathrm{CD}$ interaktif berbasis komputer dan internet.

74 | Jurnal Kredo Vol. 1 No. 2 April 2018

\section{Jenis Bahan Ajar}

Jenis bahan ajar dikelompokkan menjadi empat menurut Majid (2006:174), yaitu “(1) bahan cetak antara lain handout, buku, modul, lembar kerja siswa, brosur, leaflet, wallchart, foto/gambar, model/maket; (2) bahan ajar dengar (audio) seperti kaset, radio, piringan hitam, dan $\mathrm{CD}$ audio; (3) bahan ajar pandang dengar (audio visual) seperti video $C D$, film; dan (4) bahan ajar interaktif seperti CD interaktif." Empat jenis bahan ajar tersebut akan sangat bermanfaat dalam proses pembelajaran jika digunakan secara tepat sesuai dengan tujuan pembelajaran yang akan dicapai. Lain halnya yang disampaikan oleh Suryaman (2008:1) bahwa "jenis bahan ajar terdiri atas tujuh jenis, yaitu (1) petunjuk belajar (petunjuk mahasiswa/pendidik), (2) kompetensi yang akan dicapai, (3) isi materi pembelajaran, (4) informasi pendukung, (5) latihan-latihan, (6) petunjuk kerja (seperti lembar kerja atau LKS), (6) evaluasi, dan (7) respons atau umpan balik hasil evaluasi."

Sementara itu, Depdiknas (2008a) mengklasifikasi materi ajar menjadi lima, yaitu fakta, konsep, prinsip, prosedur, dan sikap. Adapun pengertian masing-masing sebagai berikut.

(1) Fakta, yaitu segala hal yang berwujud kenyataan dan kebenaran, meliputi nama-nama objek, peristiwa sejarah, lambang, nama tempat, nama orang, nama bagian atau komponen suatu benda, dan sebagainya.

(2) Konsep, yaitu segala sesuatu yang berwujud pengertianpengertian baru yang bisa timbul sebagai hasil pemikiran, meliputi 
definisi, pengertian, ciri khusus, hakikat, inti atau isi dan sebagainya.

(3) Prinsip, yaitu berupa hal-hal utama, pokok dan memiliki posisi penting, meliputi detail, rumus, adagum, postulat, paradigma, teorema, serta hubungan antar konsep yang menggambarkan implikasi sebab akibat.

(4) Prosedur merupakan langkahlangkah sistematis atau berurutan dalam mengerjakan sesuatu aktivitas dan kronologi suatu sistem.

(5) Sikap atau nilai merupakan hasil belajar aspek sikap, misalnya nilai kejujuran, kasih sayang, tolong-menolong, semangat dan minat belajar, dan bekerja.

Berdasarkan uraian jenis bahan ajar atau materi ajar tersebut dapat disimpulkan bahwa jenis bahan ajar bermacam-macam dilihat dari bentuk, sifat, dan fungsinya. Berkaitan dengan penelitian ini jenis materi yang dikembangkan adalah materi untuk mata kuliah Penulisan Kreatif. Pengembangan materi atau bahan ajar tersebut dikemas dalam bentuk buku teks pelajaran.

\section{Kriteria Bahan Ajar}

Bahan ajar dapat dikatakan baik apabila telah memenuhi ketentuan-ketentuan yang telah ditentukan. Ketentuan-ketentuan tersebut kemudian dijadikan karakteristik sebuah bahan ajar atau materi pelajaran. Adapun karakteristik bahan ajar yang baik menurut Depdiknas (2004) adalah "substansi materi diakumulasi dari standar kompetensi atau kompetensi dasar yang tertuang dalam kurikulum, mudah dipahami, memiliki daya tarik, dan mudah dibaca."

Dalam memilih bahan ajar pendidik harus mempertimbangkan kriteria-kriteria yang meliputi "(1) relevansi (secara psikologis dan sosiologis), (2) kompleksitas, (3) rasional/ilmiah, (4) fungsional, (5) ke-up to date-an, dan (6) komprehensif/keseimbangan" (Tim Pengembang MKDP Kurikulum dan Pembelajaran UPI 2011:152). Semetara itu, berdasarkan kriteria penilaian bahan ajar berupa buku pelajaran setidaknya ada empat syarat terpenuhi bila sebuah bahan ajar dikatakan baik, yaitu "(1) cakupan materi atau isi sesuai dengan kurikulum, (2) penyajian materi memenuhi prinsip belajar, (3) bahasa dan keterbacaan baik, dan (4) format buku atau grafika menarik" (Puskurbuk 2012).

Berdasarkan pendapatpendapat tersebut dapat disimpulkan bahwa dalam memilih, menentukan, dan mengembangkan suatu bahan ajar atau materi ajar harus memperhatikan kriteria atau karakteristik materi ajar. Dalam hal ini pendidik harus memperhatikan empat kriteria yang harus terpenuhi dalam materi ajar, yaitu (1) cakupan isi, (2) penyajian, (3) keterbacaan, dan (4) kegrafikaan. Keempat kriteria tersebut harus terpenuhi agar materi yang dipilih atau dikembangkan dapat dikatakan baik atau layak digunakan sebagai sumber informasi dalam pembelajaran.

\section{Prinsip-Prinsip Pengembangan Bahan Ajar \\ Prinsip-prinsip pengembangan yang digunakan dalam bahan ajar keterampilan Penulis Kreatif yang bermuatan nilai-nilai pendidikan karakter religius bagi mahasiswa}


Prodi PBSI, Unissula dibagi menjadi empat aspek, yaitu (1) kelayakan isi/materi, (2) penyajian, (3) kebahasaan, dan (4) kegrafikaan. Prinsip pengembangan tersebut, yaitu (1) kelayakan materi/isi dikembangkan berdasarkan prinsip kelengkapan, kesesuaian, kecukupan, kemudahan, bermuatan nilai-nilai karakter, dan relevansi, (2) penyajian dikembangkan berdasarkan prinsip menarik, kreatif, dan inovatif, sistematis, dan keaktifan, (3) kebahasaan dikembangkan berdasarkan prinsip kemudahan dan komunikatif, dan (4) kegrafikaan dikembangkan berdasarkan prinsip menarik, kreatif, dan inovatif, serta kepraktisan. Jadi, masing-masing aspek dikembangkan dengan prinsip pengembangan yang berbeda.

\section{Penulisan Kreatif}

Azizah (2011) yang menyatakan bahwa "menulis kreatif berarti mahasiswa tersebut membuat tulisan yang berkaitan dengan materi pelajaran yang telah disampaikan dengan sekreatif mungkin, sehingga pembaca akan tertarik dan memberikan komentar."

Menulis merupakan suatu kegiatan dalam menuangkan ide atau gagasan ke dalam bentuk tulisan yang dapat dimengerti seseorang kepada orang lain sebagai salah satu bentuk sarana komunikasi. Adapun menulis kreatif merupakan suatu kegiatan yang dilakukan seseorang untuk menuangkan ide, gagasan, pendapat, pengalaman, pengetahuan, dan perasaan yang membutuhkan daya imajinasi dan kreativitas agar tulisan yang dihasilkan mempunyai arti yang jelas dan memberikan kesan tersendiri bagi pembacanya. Oleh karena menulis kreatif itu penting, maka mahasiswa diharapkan mempunyai keterampilan tersebut dengan baik sebagai salah satu kecakapan hidup (life skill). Salah satu usaha yang dilakukan untuk menunjang pembelajaran keterampilan menulis kreatif tersebut, yaitu dengan cara mengembangkan bahan ajar mata kuliah Penulis Kreatif yang menarik dan efektif sehingga mahasiswa antusias dalam mengikuti proses pembelajaran serta bermuatan nilainilai pendidikan karakter religius.

\section{Nilai-Nilai Pendidikan Karakter Religius}

Secara spesifik, pendidikan karakter yang berbasis nilai religius mengacu pada nilai-nilai dasar yang terdapat dalam agama (Islam). Nilainilai karakter yang menjadi prinsip dasar pendidikan karakter banyak ditemukan dibeberapa sumber, di antaranya nilai-nilai yang bersumber dari keteladanan Rasulullah yang terjewantahkan dalam sikap dan perilaku sehari-hari beliau, yakni shiddiq (jujur), amanah (dipercaya), tabligh (menyampaikan dengan transparan), fathanah (cerdas) (Hidayatullah 2010:61-63).

\section{METODE PENELITIAN}

Penelitian ini dilakukan dengan menggunakan desain penelitian educational research and development atau biasa disebut research and development ( $R \& D)$. Menurut Sugiyono (2010:298) desain penelitian R\&D dilakukan dengan 10 tahap, tetapi pada penelitian ini peneliti memodifikasi menjadi 6 tahap penelitian sesuai dengan kebutuhan penelitian. Hasil produk penelitian ini yaitu prototipe bahan ajar mata kuliah Penulisan Kreatif yang bermuatan nilai-nilai 
pendidikan karakter religius bagi mahasiswa Prodi PBSI, FKIP, Unissula dalam bentuk buku teks.

\section{Prosedur Penelitian}

Berikut ini prosedur penelitian yang dilakukan.

1) Potensi dan masalah, meliputi (1) survei lapangan (observasi), (2) analisis teoretis dan praktis tentang bahan ajar dalam pembelajaran penulisan kreatif, dan (3) penelusuran dokumen dan penelitian-penelitian terdahulu. Pengumpulan informasi dan data, meliputi (1) mencari sumber pustaka dan hasil penelitian yang relevan dan (2) analisis kebutuhan pengembangan bahan ajar kepada mahasiswa.

2) Desain prototipe, meliputi (1) penyusunan teks, format, dan bentuk bahan ajar sesuai hasil analisis kebutuhan dan (2) penyusunan rancangan kegiatan pembelajaran.

3) Uji validasi prototipe kepada validator untuk menilai dan memberi saran dan kritik.

4) Revisi prototipe, meliputi (1) penyempurnaan produk akhir dan (2) penyempurnaan dari revisi hasil uji coba sebelumnya.

5) Uji coba terbatas untuk menguji keefektifan prototipe bahan ajar mata kuliah Penulisan Kreatif.

6) Hasil pengembangan produk berupa bahan ajar mata kuliah Penulisan Kreatif yang bermuatan nilai-nilai pendidikan karakter religius bagi mahasiswa Prodi PBSI.

\section{Subjek, Data, dan Sumber Data Penelitian}

Subjek penelitian ini disesuaikan dengan fokus penelitian, yaitu pengembangan bahan ajar mata kuliah Penulisan Kreatif yang bermuatan nilai-nilai pendidikan karakter religius bagi mahasiswa Prodi PBSI, FKIP, Unissula. Data dalam penelitian ini ada tiga, yaitu data pertama diperoleh dari hasil analisis kebutuhan penyusunan bahan ajar, yaitu skor kecenderungan pilihan kebutuhan pengembangan bahan ajar mata kuliah Penulisan Kreatif yang bermuatan nilai-nilai pendidikan karakter religius bagi mahasiswa Prodi PBSI. Data kedua diperoleh dari hasil analisis kebutuhan terhadap kebutuhan pengembangan bahan ajar dan analisis teori untuk merumuskan karakteristik pengembangan berupa prinsip-prinsip pengembangan bahan ajar mata kuliah Penulisan Kreatif yang bermuatan nilai-nilai pendidikan karakter religius bagi mahasiswa Prodi PBSI, FKIP, Unissula. Data ketiga diperoleh dari hasil uji validasi berupa skor penilaian prototipe bahan ajar mata kuliah Penulisan Kreatif yang bermuatan nilai-nilai pendidikan karakter religius bagi mahasiswa Prodi PBSI, FKIP, Unissula. Sumber data penelitian ini yaitu mahasiswa, dosen pengampu mata kuliah atau dosen ahli. Kedua sumber data tersebut berkaitan erat karena jika salah sumber data tidak ada akan mengurangi kevalidan hasil penelitian ini.

\section{Waktu dan Tempat Penelitian}

Penelitian ini dilakukan pada saat proses perkuliahan mata kuliah Penulisan Kreatif semester tiga (ganjil) tahun akademik 2017/2018 di Prodi Pendidikan Bahasa dan Sastra Indonesia, FKIP, Unissula. 
Variabel penelitian ini meliputi variabel bebas dan variabel terikat. Variabel bebas penelitian ini yaitu bahan ajar mata kuliah Penulisan Kreatif yang bermuatan nilai-nilai pendidikan karakter religius. Adapun variabel terikat penelitian ini yaitu pendidikan nilai karakter religius.

\section{Instrumen Penelitian}

Sesuai dengan fokus penelitian ini, yaitu pengembangan bahan ajar mata kuliah Penulisan Kreatif yang bermuatan nilai-nilai pendidikan karakter religius bagi mahasiswa Prodi PBSI, FKIP, Unissula maka dibutuhkan instrumen yang berbeda. Pertama, panduan wawancara sebagai pedoman dalam wawancara kepada mahasiswa. Wawancara dilakukan secara terbuka untuk menjaring data pertama. Kedua, angket kebutuhan (kuesioner) yang digunakan untuk mengupas hal-hal yang terkait dengan substansi maupun fisik pengembangan bahan ajar mata kuliah Penulis Kreatif. Ketiga, lembar uji validasi prototipe yang ditujukan kepada dosen ahli untuk memperoleh hasil uji validasi prototipe bahan ajar mata kuliah Penulisan Kreatif yang akan membantu peneliti mengetahui kelemahan prototipe bahan ajar yang dikembangkan. Keempat, instrumen tes untuk mengetahui keefektifan bahan ajar mata kuliah Penulisan Kreatif.

\section{Teknik Pengumpulan Data}

Pengumpulan data dalam penelitian ini disesuaikan dengan jenis instrumen yang digunakan. Teknik yang digunakan untuk memperoleh data pertama tentang kebutuhan pengembangan bahan ajar, yaitu teknik wawancara dan teknik angket kebutuhan. Teknik yang digunakan untuk memperoleh data kedua untuk merumuskan karakteristik bahan ajar yaitu angket kebutuhan. Teknik yang digunakan untuk memperoleh data ketiga tentang hasil uji validasi prototipe yaitu teknik angket (lembar) uji validasi yang diperoleh dari dosen ahli. Selain itu, untuk mendokumentasikan penelitian ini maka dilakukan teknik dokumentasi.

\section{Teknik Analisis Data}

Data yang telah dikumpulkan kemudian dikelompokkan menjadi dua. Pertama, data dari analisis kebutuhan pengembangan bahan ajar mata kuliah Penulisan Kreatif yang bermuatan nilai-nilai pendidikan karakter religius yang didapat dari hasil angket kebutuhan mahasiswa. Kedua, data dari hasil uji validasi prototipe dosen ahli sebagai acuan dalam proses perbaikan atau revisi produk yang dikembangkan.

Teknik analisis data yang digunakan dalam penelitian ini yaitu teknik analisis deskriptif kualitatif. Analisis deskriptif kualitatif tersebut digunakan untuk menganalisis data dan informasi dari analisis kebutuhan pengembangan bahan ajar mata kuliah Penulisan Kreatif yang bermuatan nilai-nilai pendidikan karakter religius bagi mahasiswa Prodi PBSI, FKIP, Unissula. Berdaarkan hasil analisis tersebut diketahui kebutuhan terhadap pengembangan bahan ajar mata kuliah Penulis Kreatif yang bermuatan nilai-nilai pendidikan karakter religius bagi mahasiswa Prodi PBSI, FKIP, Unissula. Analisis dilakukan dengan menggunakan analisis deskriptif kualitatif untuk mengungkap dan memperoleh data 
kebutuhan pengembangan bahan ajar.

\section{HASIL PENELITIAN DAN PEMBAHASAN}

Kebutuhan Pengembangan Bahan Ajar Mata Kuliah Penulisan Kreatif Bermuatan Nilai-Nilai Pendidikan Karakter Religius bagi Mahasiswa pada Prodi Pendidikan Bahasa dan Sastra Indonesia, FKIP, Unissula

Keberadaan bahan ajar sangat penting untuk menunjang proses pembelajaran. Bahan ajar yang digunakan pun harus sesuai dengan kebutuhan mahasiswa dan sesuai dengan capaian pembelajaran mata kuliah. Pada pengembangan bahan ajar Penulisan Kreatif, mahasiswa Prodi Pendidikan Bahasa dan Sastra Indonesia, FKIP, Unissula membutuhkan bahan ajar yang dapat memberikan mereka informasi dan materi tentang menulis kreatif. Adapun kebutuhan pengembangan bahan ajar tersebut dapat dipaparkan sebagai berikut.

\section{a. Aspek Kelayakan Isi}

Dari aspek kelayakan isi mahasiswa mengehendaki bahan ajar Penulisan Kreatif yang memuat isi berikut ini.

(1) Sumber Materi

Sumber materi yang digunakan berasal dari berbagai sumber baik dari buku-buku referensi yang sudah ada, modul/handout maupun dari internet.

(2) Cakupan Materi

Cakupan materi meliputi menulis puisi, cerpen, naskah drama, biografi, anekdot, cerita lokal seperti fabel, dongeng, mite, legenda, dan lain-lain.
(3) Materi Pengantar

Dalam bahan ajar Penulisan Kreatif mahasiswa menghendaki adanya materi pengantar. Materi pengantar tersebut berfungsi untuk memberi gambaran awal kepada mahasiswa terhadap materi yang akan dipelajari.

(4) Jenis Materi

Jenis materi yang dikehendaki mahasiswa adalah materi yang bersifat pemahaman. Mahasiswa tidak menghendaki materi yang sifatnya hafalan. Untuk jenis materi adalah prosedural.

(5) Karakteristik Materi

Karakteristik materi ajar yang dikehendaki mahasiswa adalah materi yang mudah dipahami dan sesuai dengan tingkat pengetahuan. Selain itu, mahasiswa juga menghendaki materi yang dapat menarik dan memotivasi mereka untuk belajar.

(6) Isi Materi

Dari aspek isi materi mahasiswa menghendaki adanya uraian materi yang disertai dengan contoh dan latihan. Contoh-contoh yang dikehendaki mahasiswa adalah contoh yang mengandung nilainilai pendidikan karakter religius. Fungsi contoh tersebut adalah untuk memperjelas pemahaman mereka terhadap materi yang dipelajari sebelum mereka berlatih menulis kreatif. Mahasiswa juga menghendaki dalam materi ajar keterampilan menulis kreatif terdapat latihanlatihan yang dapat membuat mahasiswa aktif. Selain adanya contoh dan latihan, mahasiswa juga menghendaki adanya 
informasi-informasi tambahan yang berkaitan dengan materi pembelajaran untuk menambah wawasan mereka.

(7) Integrasi Nilai-Nilai Pendidikan Karakter Religius Muatan nilai-nilai pendidikan karakter religius dalam bahan ajar Penulisan Kreatif yang dikehendaki mahasiswa termuat dalam tema baik puisi, cerpen, drama atau tulisan yang lainnya.

\section{b. Aspek Kelayakan Penyajian Materi}

Dari aspek kelayakan isi mahasiswa mengehendaki bahan ajar Penulisan Kreatif yang memuat isi berikut ini.

(1) Sistematika Penyajian

pada $\begin{gathered}\text { Sistematika } \\ \text { bahan ajar yang }\end{gathered}$
dikehendaki mahasiswa, yaitu runtut dan lengkap. Sistematika penyajian tersebut meliputi judul, prakata, petunjuk penggunaan buku, daftar isi, pendahuluan, materi, contoh, latihan, dan daftar pustaka.

(2) Penyajian Petunjuk Penggunaan Dalam bahan ajar Penulis Kreatif mahasiswa menghendaki adanya petunjuk penggunaan untuk memandu mereka ketika belajar. Penyajian petunjuk penggunaan tersebut meliputi petunjuk penggunaan buku dan peta konsep buku. Selain itu, pada bahan ajar tersebut juga dilengkapi dengan gambargambar petunjuk.

(3) Penyajian Ilustrasi

Penyajian ilustrasi yang dikehendaki mahasiswa meliputi ilustrasi yang berupa cerita dan gambar-gambar. Penyajian cerita dan gambar-gambar tersebut harus relevan dan dapat

80 | Jurnal Kredo

Vol. 1 No. 2 April 2018 mendukung pemahaman mahasiswa. Dengan ilustrasi, uraian dapat dibuat menjadi lebih singkat, jelas, terfokus, dan menarik.

(4) Penyajian Materi Penyajian materi yang dikehendaki mahasiswa disajikan dengan runtut, mudah dipahami, menarik, dan kreatif.

(5) Penyajian Nilai-Nilai Pendidikan Karakter Religius

Muatan nilai-nilai pendidikan karakter pada bahan ajar termuat dalam ilustrasi dan tema cerita dan gambar-gambar yang mendukung materi ajar.

(6) Penyajian Contoh

Pada aspek penyajian contoh mahasiswa menghendaki contoh-contoh disajikan setelah uraian materi. Hal tersebut dimaksudkan agar mahasiswa lebih paham terhadap materi yang dipelajari. Contoh-contoh tersebut dapat memberikan gambaran nyata bagi mahasiswa, sehingga mereka dapat mengaplikasikan materi dalam kehidupan nyata. Adapun jumlah contoh yang dikehendaki mahasiswa disesuaikan dengan materi. Artinya setiap submateri disertai dengan contoh-contoh.

(7) Penyajian Evaluasi

Evaluasi diberikan untuk mengukur hasil belajar mahasiswa baik ranah kognitif maupun psikomotorik. Dalam pengembangan bahan ajar Penulisan Kreatif yang bermuatan nilai-nilai pendidikan karakter, penyajian evaluasi disajikan setelah uraian materi dan contoh. Adapun bentuk evaluasi berupa soal latihan untuk menulis kreatif.

(8) Penyajian Istilah-Istilah 
Penyajian istilah-istilah yang digunakan dalam bahan ajar Penulisan Kreatif menurut mahasiswa dijelaskan secara langsung dalam materi. Selain itu, agar lebih mudah mencari arti istilah-istilah yang digunakan dalam bahan ajar ditambahkan glosarium pada bagian akhir buku.

(9) Penyajian Daftar Pustaka

Daftar pustaka merupakan bagian dari kelengkapan isi buku. Daftar rujukan sumber materi yang digunakan dalam bahan ajar keterampilan menulis kreatif dituliskan dalam daftar pustaka. Hal tersebut bertujuan agar pengguna baik mahasiswa maupun dosen serta pihak lain dapat mengetahui sumber materi apa saja yang digunakan. Dalam bahan ajar Penulis Kreatif daftar pustaka disajikan di bagian akhir buku.

(10) Penyajian Biografi Penulis

Selain daftar pustaka kelengkapan buku yang lain yaitu biografi penulis. Biografi penulis ini berisi informasi tentang latar belakang penulis buku. Hal tersebut bertujuan agar pembaca dapat mengetahui informasi penulis buku. Biografi penulis ini disajikan di bagian akhir buku setelah penyajian daftar pustaka.

\section{c. Aspek Kelayakan Kebahasaan}

Aspek kelayakan

kebahasaan dalam pengembangan bahan ajar Penulisan Kreatif dapat dipaparkan sebagai berikut.

1) Bahasa yang digunakan sesuai dengan tingkat pengetahuan dan tingkat perkembangan pemahaman kemampuan berpikir mahasiswa (kosakata jelas, diksi tepat, dan ejaan benar).

2) Bahasa yang digunakan dalam materi menulis kreatif sesuai dengan situasi sosial-emosional mahasiswa (usia dewasa dan lingkungan).

3) Materi disajikan sesuai dengan kaidah bahasa Indonesia yang baik dan benar (sesuai EBI).

4) Materi disajikan dengan memperhatikan kaidah struktur kalimat.

5) Materi disajikan dengan menggunakan kalimat efektif.

6) Bahasa yang digunakan komunikatif.

7) Istilah-istilah yang digunakan mudah dipahami.

\section{d. Aspek Kelayakan Kegrafikaan}

Aspek kelayakan kebahasaan dalam pengembangan bahan ajar Penulis Kreatif dapat dipaparkan sebagai berikut.

(1) Judul dan Jenis Tulisan

Pilihan judul terbanyak yang dikehendaki mahasiswa yaitu Eksis dan Religius dengan Menulis Kreatif. Adapun jenis tulisan yang digunakan baik untuk tulisan judul maupun tulisan untuk uraian materi disesuaikan dengan kebutuhan. Artinya terdapat perbedaan jenis tulisan untuk masing-masing komponen agar lebih variatif, sehingga lebih menarik dan kreatif.

(2) Jenis Gambar

Jenis gambar yang digunakan adalah perpaduan antara gambar benda mati dan benda hidup. Gambar-gambar tersebut sebagai ilustrasi pendukung untuk memperjelas materi sehingga mudah dipahami mahasiswa. Ilustrasi 
gambar-gambar tersebut disajikan dalam kulit atau cover buku dan penyajian materi. Ilustrasi gambar pada cover buku berupa gambar orang sedang menulis. Desain warna yang digunakan adalah warnawarna cerah, tetapi tidak mencolok. Adapun ilustrasi gambar dalam penyajian materi adalah gambar-gambar yang bervariasi dan berwarna.

(3) Jenis dan Ukuran Kertas Jenis kertas yang digunakan untuk cover yaitu soft cover dan jenis kertas untuk bagian isi yaitu HVS 80 gram. Adapun ukuran kertas yang digunakan yaitu A4 $(21 \mathrm{~cm} \mathrm{x}$ $29,7 \mathrm{~cm}$ ).

(4) Ukuran dan Tebal Buku

Ukuran buku teks bahan ajar Penulisan Kreatif adalah seperti buku referensi pada umumnya, yaitu B5 $(18,2 \mathrm{~cm} \mathrm{x}$ $25,7 \mathrm{~cm}$ ). Model buku didesain simpel, praktis, dan tidak terlalu tebal, tetapi substansi lengkap.

(5) Warna

Pemilihan warna yang digunakan pada cover buku Penulis Kreatif yaitu warnawarna cerah yang bervariasi, tetapi tidak mencolok. Adapun warna pada layout buku menyesuaikan dengan desain warna pada cover, sehingga tampak serasi dengan dipadukan warna-warna lain yang senada agar tidak mencolok dan nyaman dilihat.

\section{Karakteristik Bahan Ajar Mata Kuliah Penulisan Kreatif Bermuatan Nilai-Nilai Pendidikan Karakter Religius bagi Mahasiswa Prodi Pendidikan Bahasa dan Sastra Indonesia, FKIP, Unissula}

Sesuai dengan yang diungkapkan Direktorat Jenderal Pendidikan Dasar dan Menengah Departemen Pendidikan Nasional Tahun 2003 bahwa bahan ajar memiliki beberapa karakteristik, yaitu self instructional, self contained, stand alone, adaptive, dan user friendly. Mengacu hal tersebut maka pengembangan bahan ajar Penulisan Kreatif yang bermuatan nilai-nilai pendidikan karakter religius bagi mahasiswa Prodi PBSI, FKIP, Unissula memiliki karakteristik yang selanjutnya menjadi prinsip-prinsip pengembangan bahan ajar sebagai berikut.

1) Self instructional, yaitu bahan ajar dapat membuat mahasiswa mampu membelajarkan diri sendiri dengan bahan ajar yang dikembangkan. Untuk memenuhi karakter self instructional, maka dalam bahan ajar Penulisan Kreatif terdapat tujuan yang dirumuskan dengan jelas, baik tujuan akhir maupun tujuan antara. Selain itu, dengan bahan ajar Penulisan Kreatif ini akan memudahkan mahasiswa belajar secara tuntas dengan memberikan materi pembelajaran yang dikemas ke dalam unit-unit atau kegiatan yang lebih spesifik.

2) Self contained yaitu seluruh materi pelajaran dari satu unit kompetensi atau subkompetensi yang dipelajari terdapat dalam satu bahan ajar secara utuh. Jadi, dalam bahan ajar Penulisan Kreatif memuat seluruh bagianbagiannya dalam satu buku secara utuh untuk memudahkan pembaca mempelajari bahan ajar tersebut.

3) Stand alone (berdiri sendiri) yaitu bahan ajar yang dikembangkan tidak tergantung pada bahan ajar

82 | Jurnal Kredo 
lain atau tidak harus digunakan bersama-sama dengan bahan ajar lain. Bahan ajar Penulisan Kreatif dapat digunakan sendiri tanpa bergantung dengan bahan ajar lain.

4)Adaptive yaitu bahan ajar hendaknya memiliki daya adaptif yang tinggi terhadap perkembangan ilmu danteknologi. Bahan ajar Penulisan Kreatif memuat materi-materi yang sekiranya dapat menambah pengetahuan pembaca terkait perkembangan zaman atau lebih khususnya perkembangan ilmu dan teknologi.

5) User friendly yaitu setiap intruksi dan paparan informasi yang tampil bersifat membantu dan bersahabat dengan pemakainya, termasuk kemudahan pemakai dalam merespon dan mengakses sesuai dengan keinginan. Jadi, bahan ajar Penulisan Kreatif dikembangkan untuk memudahkan pembaca untuk mendapat informasi dengan sejelas-jelasnya.

Hasil Uji Validasi Prototipe Bahan Ajar Mata Kuliah Penulisan Kreatif Bermuatan Nilai-Nilai Pendidikan Karakter Religius bagi Mahasiswa Prodi Pendidikan Bahasa dan Sastra Indonesia, FKIP, Unissula

Dalam melakukan uji validasi prototipe, peneliti melibatkan beberapa ahli sesuai dengan bidangnya, yaitu Dr. Turahmat, M. Pd. sebagai ahli sastra dan penulisan kreatif, Evi Chamalah, M. Pd. Sebagai ahli bahasa, dan Dr. Nurudin, M. Pd. sebagai ahli pendidikan nilai karakter religius. Berdasarkan hasil uji validasi ahli diperoleh hasil penilaian berikut ini.

Tabel 1 Hasil Penilaian Validator

\begin{tabular}{|c|l|c|c|c|c|}
\hline \multirow{2}{*}{$\begin{array}{c}\text { N } \\
\text { o }\end{array}$} & \multicolumn{1}{|c|}{ Aspek } & \multicolumn{3}{|c|}{ Penilaian } & $\begin{array}{c}\text { Rata- } \\
\text { rata }\end{array}$ \\
\cline { 3 - 6 } & & Ahli 1 & Ahli 2 & Ahli 3 & \\
\hline 1. & $\begin{array}{l}\text { Kelayakan } \\
\text { isi }\end{array}$ & 21 & 20 & 23 & \\
\hline 2. & Kebahasaan & 22 & 23 & 22 & \\
\hline 3. & Penyajian & 20 & 22 & 23 & \\
\hline 4 & Kegrafikaan & 21 & 20 & 21 & \\
\hline & Jumlah & 84 & 85 & 89 & $\mathbf{8 6}$ \\
\hline
\end{tabular}

Dari data pada tabel tersebut diketahui skor rata-rata penilaian 86 dengan kategori sangat baik. Dalam proses validasi ahli pendidikan karakter religius menyarankan untuk memperbaiki layout buku agar nilai karakter religius lebih mengena sesuai dengan judul yang diangkat.

Hasil Uji Coba Terbatas Bahan Ajar Mata Kuliah Penulisan
Kreatif Bermuatan Nilai-Nilai Pendidikan Karakter Religius bagi Mahasiswa Prodi Pendidikan Bahasa dan Sastra Indonesia, FKIP, Unissula

Hasil uji keefektifan bahan ajar tersebut ditentukan dengan pemerolehan nilai awal dan nilai akhir. Untuk mengetahui perbedaan pemerolehan nilai tersebut maka 
dilakukan uji perbedaan. Uji perbedaan di sini dimaksudkan untuk membandingkan rataan suatu variabel antara nilai hasil awal dan akhir. Adapun hipotesis statistik yang digunakan sebagai berikut.

$\mathrm{H}_{0}: \mu_{1}=\mu_{2}$ ( rata-rata nilai awal sama dengan rata-rata nilai akhir
$\mathrm{H}_{1}: \mu_{1} \neq \mu_{2}$ (rata-rata nilai awal tidak sama dengan rata-rata nilai akhir)

Dalam penelitian ini analisis data uji perbedaan menggunakan Independent Sample Test dan diperoleh hasil yang dapat dilihat pada Tabel 2 berikut.

Tabel 2 Independent Samples Test

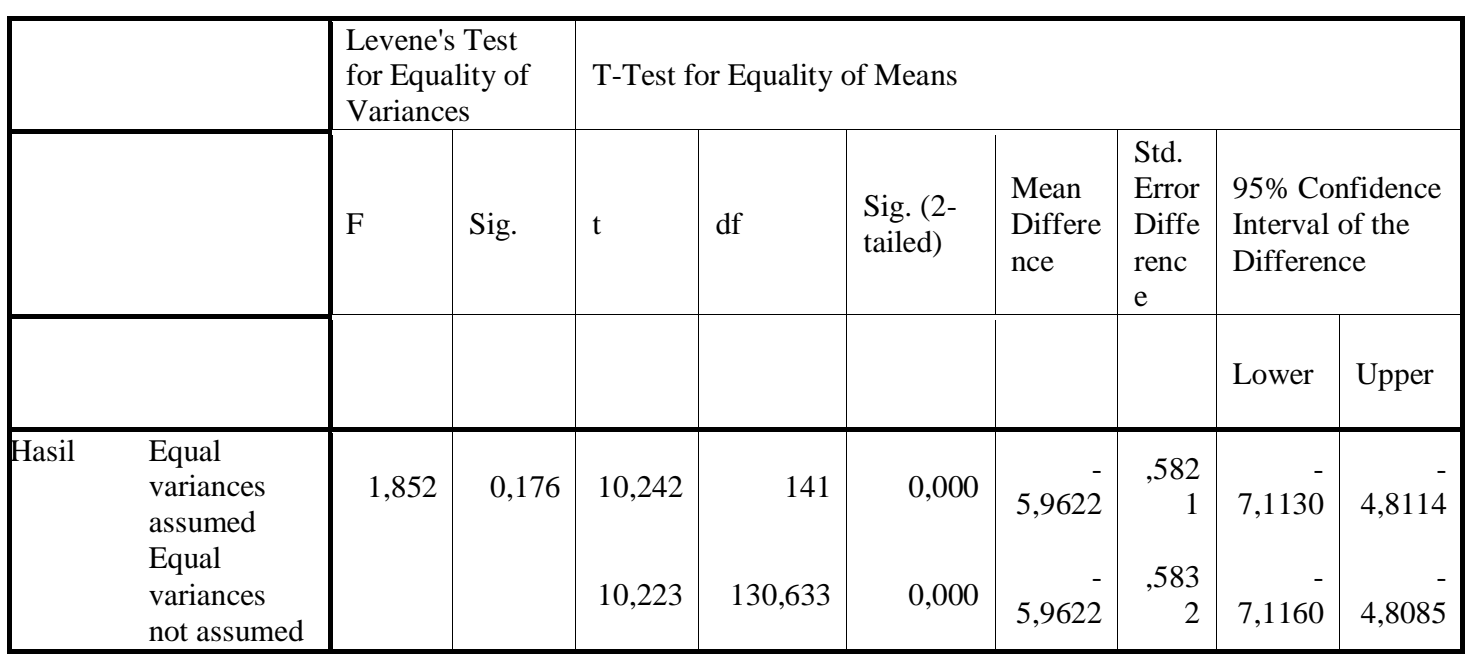

Keterangan:

- $\alpha$ adalah tingkat kegagalan 5\% $(0,05)$ dari suatu penelitian

- Jika tingkat Signifikan < $\alpha$ $(0,05)$, maka terdapat perbedaan yang signifikan dari kedua sampel (variabel).

- Jika tingkat Signifikan $>\alpha$ $(0,05)$, maka tidak terdapat perbedaan yang signifikan dari kedua sampel (variabel).

Berdasarkan data pada tabel tersebut dapat diketahui bahwa dari nilai kesamaan dua varians diperoleh $\mathrm{F}=1,852$ yang mengasumsikan bahwa kedua varian berbeda dengan nilai $\mathrm{t}=10,242$ dengan derajat kebebasan $(\mathrm{df})=141$, dan sig $=$ $0,176=17,6 \%$ (lebih dari 5\%). Hal ini berarti $\mathrm{H}_{0}$ diterima, artinya kedua sampel mempunyai varians yang sama. Selanjutnya dipilih Equal 84 | Jurnal Kredo

Vol. 1 No. 2 April 2018
Variance Assumed, diperoleh sig = $0,000=0 \%<5 \%$. Hal ini berarti $\mathrm{H}_{0}$ ditolak, artinya kedua populasi mempunyai nilai rata-rata ketuntasan yang berbeda.

Uji kesamaan dua rata-rata antara tes awal dan tes akhir menggunakan hipotesis sebagai berikut.

Ho : tidak terdapat perbedaan hasil belajar antara mahasiswa pada tes awal dan tes akhir.

$\mathrm{Ha}$ : terdapat perbedaan hasil belajar antara mahasiswa pada tes awal dan tes akhir.

Adapun untuk mengetahui kebenaran hipotesis digunakan $t$ hitung $>\mathrm{t}$ tabel. Berdasarkan harga Uji- $t$ diketahui $\mathrm{t}$ sebesar 10,242 dengan tingkat signifikansi (sig) sebesar 0,000 dan derajat kebebasan $(\mathrm{df})=141$ dengan taraf kepercayaan 
95\%, dapat disimpulkan bahwa Ho diterima dan terdapat perbedaan yang signifikan antara rata-rata nilai mahasiswa sebelum dan sesudah belajar menulis kreatif dengan menggunakan bahan ajar Penulisan Kreatif karena $t$ hitung $(10,242)>t$ tabel (0,679). Dengan demikian, dapat dikatakan bahwa bahan ajar mata kuliah Penulis Kreatif yang bermuatan nilai-nilai pendidikan karakter religius bagi mahasiswa Prodi PBSI, Unissula dapat meningkatkan kemampuan menulis kreatif peserta didik. Oleh karena itu, bahan ajar tersebut efektif dan diterima.
Prototipe Bahan Ajar Mata Kuliah Penulisan Kreatif Bermuatan Nilai-Nilai Pendidikan Karakter Religius bagi Mahasiswa Prodi Pendidikan Bahasa dan Sastra Indonesia, FKIP, Unissula

Setelah diuji validasi dan direvisi maka diperoleh prototipe bahan ajar mata kuliah Penulisan Kreatif bermuatan nilai-nilai pendidikan karakter religius bagi mahasiswa Prodi Pendidikan Bahasa dan Sastra Indonesia, FKIP, Unissula sebagai berikut:

Judul

Penulis

\section{Gambar 1 Sampul Bahan Ajar Penulisan Kreatif}

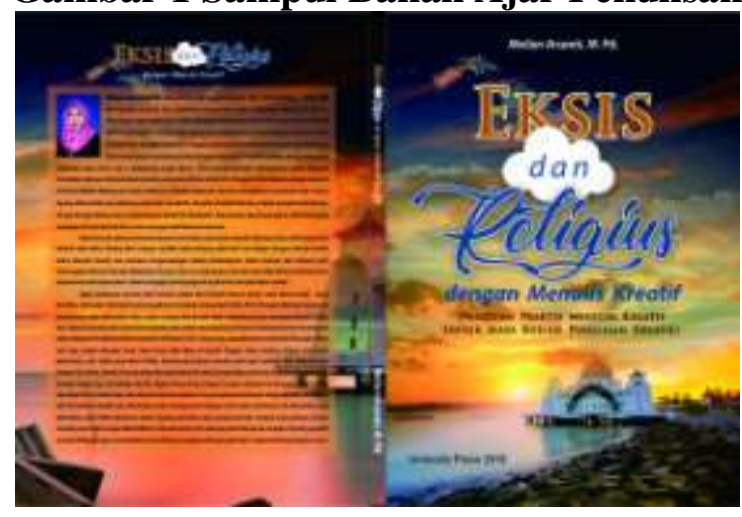

Daftar Isi

HALAMAN JUDUL

HALAMAN PENGESAHAN

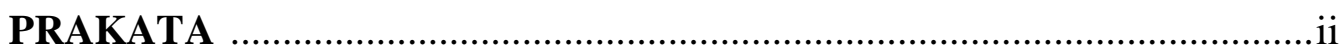

KATA PENGANTAR

DAFTAR ISI

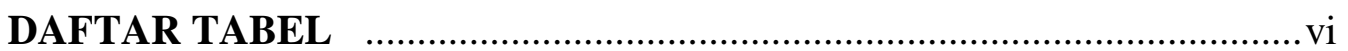

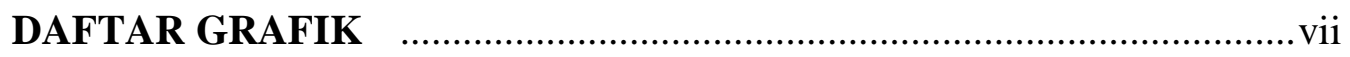

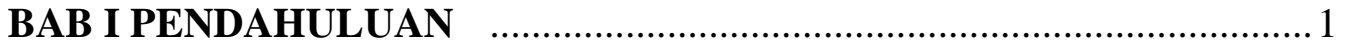

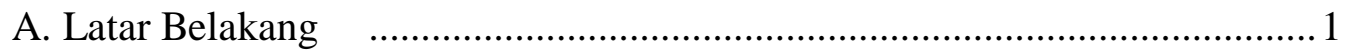

B. Kaitan Buku ajar dengan Materi Kuliah ................................................ 1

C. Lingkup dan Sistematika …...................................................................... 2

BAB II NILAI RELIGIUS DALAM KARYA KREATIF ….................. 2

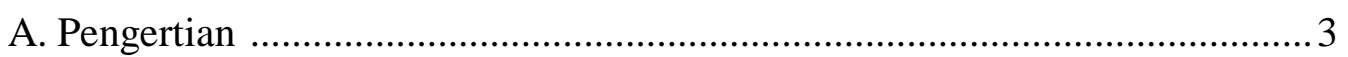




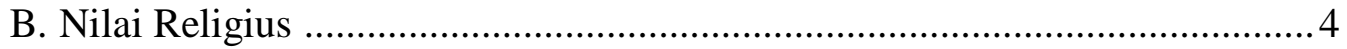

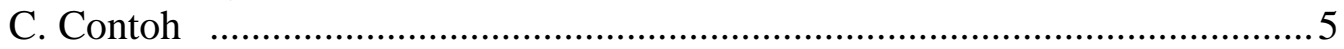

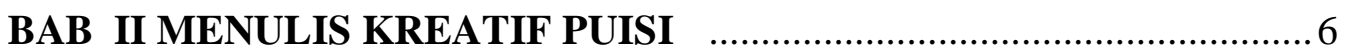

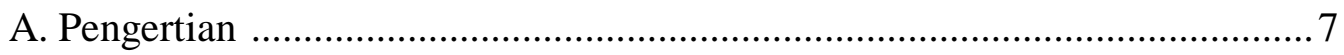

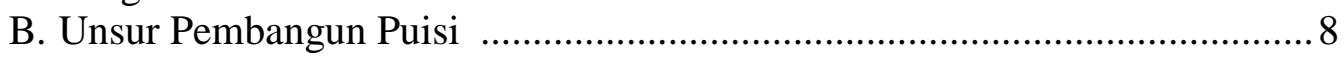

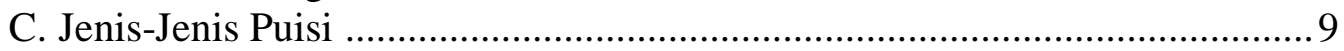

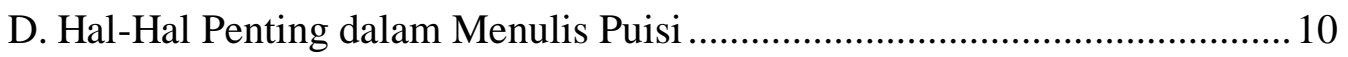

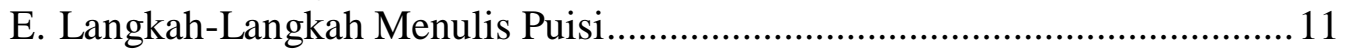

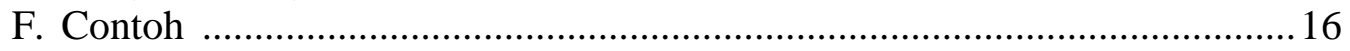

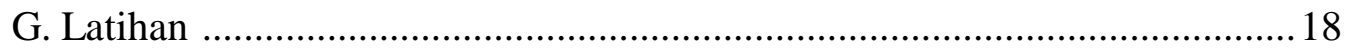

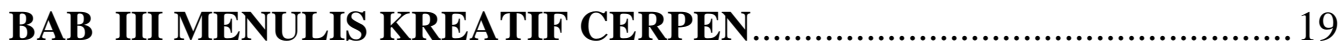

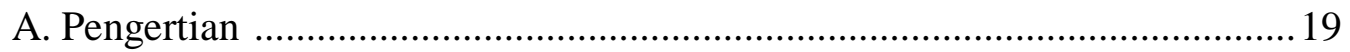

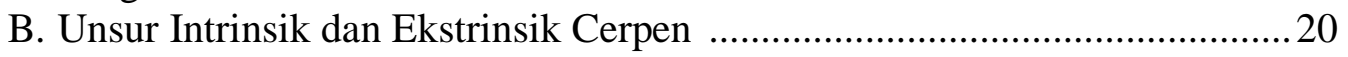

C. Hal-Hal Penting dalam Menulis Cerpen ................................................... 22

D. Langkah-Langkah Menulis Cerpen ..........................................................2 23

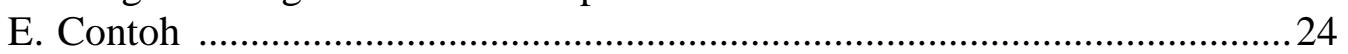

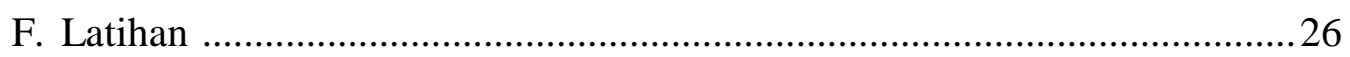

BAB IV MENULIS KREATIF NASKAH DRAMA …...........................2

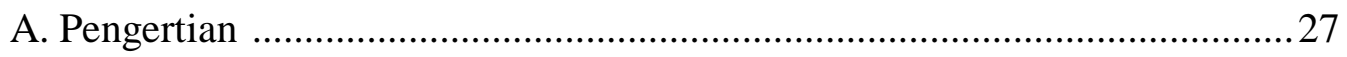

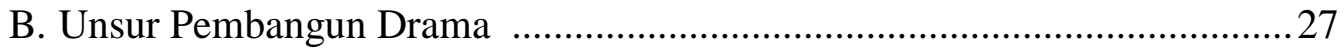

C. Hal-Hal Penting dalam Menulis Naskah Drama ..........................................28

D. Langkah-Langkah Menulis Naskah Drama..............................................29

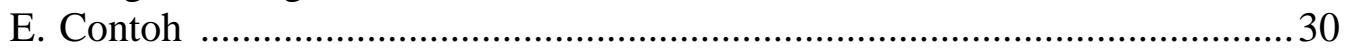

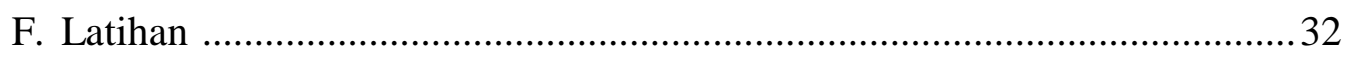

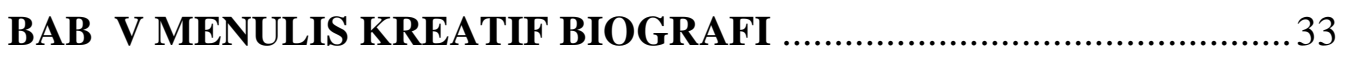

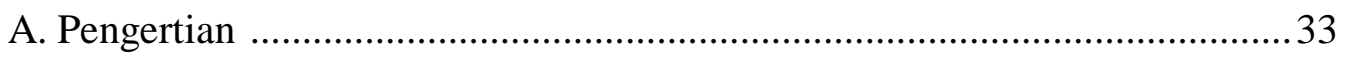

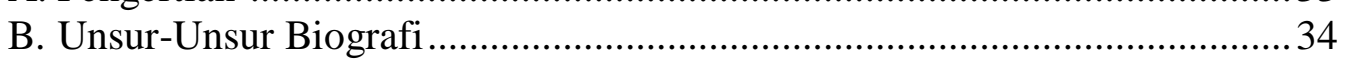

C. Hal-Hal Penting dalam Menulis Biografi................................................... 35

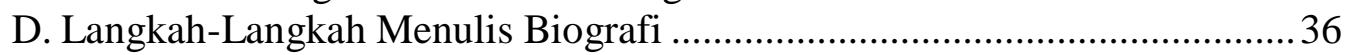

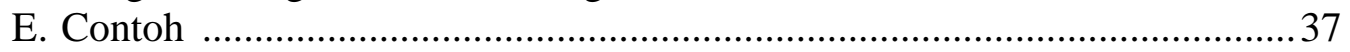

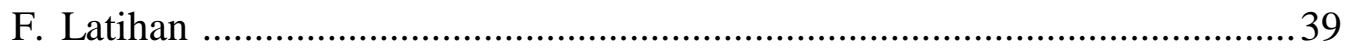

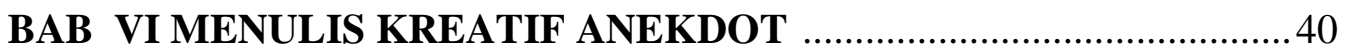

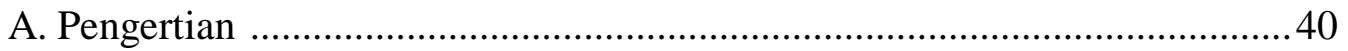

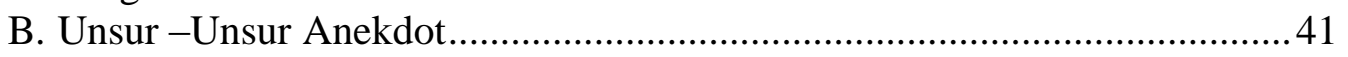

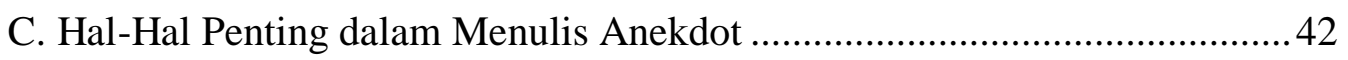

D. Langkah-Langkah Menulis Anekdot........................................................ 43

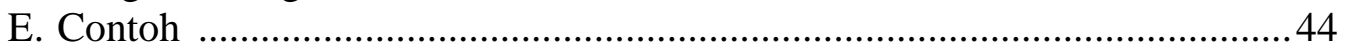

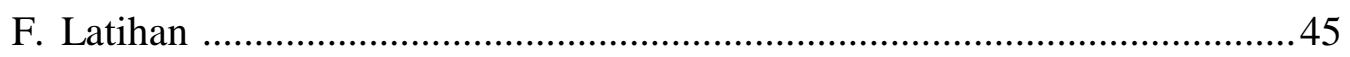

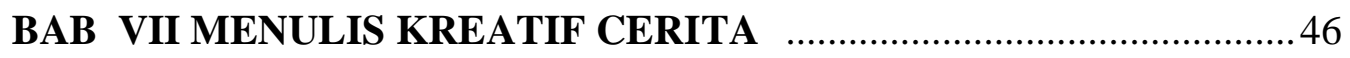

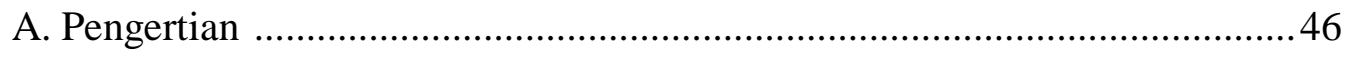

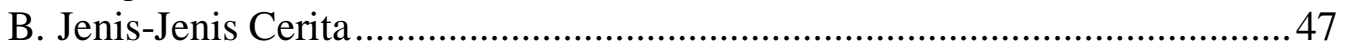

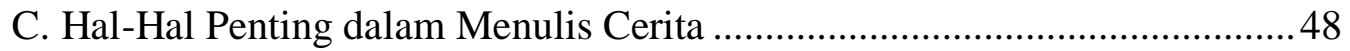

D. Langkah-Langkah Menulis Cerita.............................................................49

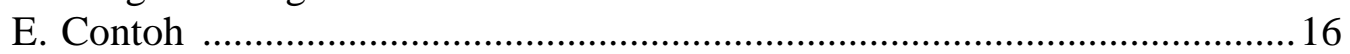

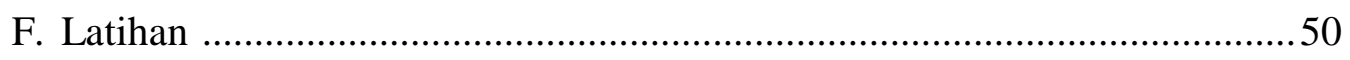

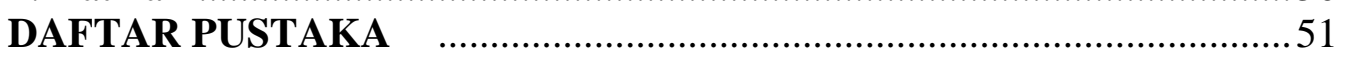

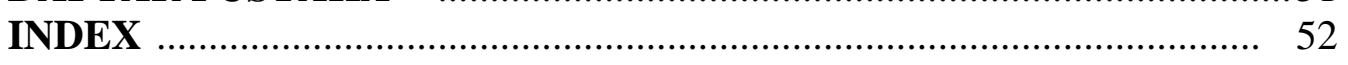

LAMPIRAN

86 | Jurnal Kredo Vol. 1 No. 2 April 2018 
Secara spesifik, pendidikan karakter yang berbasis nilai religius mengacu pada nilai-nilai dasar yang terdapat dalam agama (Islam). Nilainilai pendidikan karakter religius yang termuat dalam bahan ajar tersebut bersumber dari nilai-nilai yang bersumber dari keteladanan Rasulullah yang terjewantahkan dalam sikap dan perilaku sehari-hari beliau, yakni shiddiq (jujur), amanah (dipercaya), tabligh (menyampaikan dengan transparan), fathanah (cerdas). Berikut akan dijelaskan secara lebih rinci dari keempat sifat tersebut.

Shiddiq adalah sebuah kenyataan yang benar yang tercermin dalam perkataan, perbuatan atau tindakan dan keadaan batinnya. Pengertian shiddiq ini dapat dijabarkan ke dalam butir-butir a) memiliki sistem keyakinan untuk merealisasikan visi, misi dan tujuan; dan b) memiliki kemampuan kepribadian yang mantap, stabil, dewasa, arif, jujur, dan berwibawa, menjadi teladan bagi mahasiswa dan berakhlak mulia.

Amanah adalah sebuah kepercayaan yang harus diemban dalam mewujudkan sesuatu yang dilakukan dengan penuh komitmen, kompeten, kerja keras, dan konsisten. Pengertian amanah ini dapat dijabarkan ke dalam butir-butir a) rasa memiliki dan tanggung jawab yang tinggi; b) memiliki kemampuan mengembangkan potensi secara optimal; c) memiliki kemampuan mengamankan dan menjaga kelangsungan hidup; dan d) memiliki kemampuan membangun kemitraan dan jaringan.

Tabligh adalah sebuah upaya merealisasikan pesan atau misi tertentu yang dilakukan dengan pendekatan atau metode tertentu. Jabaran pengertian ini diarahkan pada a) memiliki kemampuan merealisasikan pesan atau misi; b) memiliki kemampuan berinteraksi secara efektif; dan c) memiliki kemampuan menerapkan pendekatan dan metodik yang tepat.

Fathanah adalah sebuah kecerdasan, kemahiran, atau penguasaan bidang tertentu yang mencakup kecerdasan intelektual, emosional dan spiritual. Karakteristik jiwa fathanah meliputi arif dan bijak, integritas tinggi, kesadaran untuk belajar, sikap proaktif, orientasi kepada Tuhan, terpercaya dan ternama, menjadi yang terbaik, empati dan perasaan terharu, kematangan emosi, keseimbangan, jiwa penyampai misi, dan jiwa kompetisi. Sifat fathanah ini dapat dijabarkan ke dalam butir-butir: a) memiliki kemampuan adaptif terhadap perkembangan dan perubahan zaman; b) memiliki kompetensi yang unggul, bermutu dan berdaya saing; dan c) memiliki kecerdasan intelektual, emosi, dan spiritual.

Selain bersumber dari sifat Nabi Muhammad, nilai-nilai karakter religius dalam bahan ajar tersebut juga bersumber dari teks-teks agama, baik Alquran, hadits, maupun katakata hikmah para ulama. Dalam teksteks agama tersebut banyak ditemukan anjuran untuk bersikap/berperilaku terpuji (akhlak al-karîmah), seperti ramah, adil, arif, sabar, syukur, sopan, peduli, tanggap, tanggung jawab, mandiri, cinta kebersihan, cinta kedamaian, dan lain sebagainya sebagaimana yang melekat pada diri Rasulullah. 
Sebaliknya menghindarkan diri dari perilaku tercela (akhlak almadzmûmah).

Selain itu, dalam ajaran agama Islam terdapat nilai-nilai pokok yang terkandung atau bersumber dari Alquran dan hadist yang menjadi pedoman hidup umatnya. Nilai-nilai tersebut, yaitu aqidah, syari'ah, dan akhlaq. Nilai aqidah (keyakinan atau kepercayaan) berhubungan secara vertikal dengan Allah Swt. (Hablun Min Allah). Adapun nilai syari'ah (pengalaman) yaitu implementasi dari aqidah yang berupa hubungan horizontal dengan manusia (Hablun Min an-Naas) yang berupa perbuatan sebagai konsekuensi dari kepercayaan. Selanjutnya adalah nilai akhlaq (etika vertikal horizontal) yang merupakan aplikasi dari aqidah dan muamalah. Nilai akhlak berisi dorongan hati untuk berbuat sebaik-baiknya meskipun tanpa pengawasan pihak lain, karena percaya Allah Maha Melihat dan Maha Mengetahui (Ibrahim 2007:7).

Semua muatan nilai karakter religius tersebut dimuatkan dalam ilustrasi, tema, cerita, gambar pendukung, dan contoh penulisan kreatif seperti puisi, cerpen, naskah drama, teks anekdot, dan lain-lain. Misalnya pada bagian menulis kreatif puisi dalam bahan ajar tersebut mahasiswa diberi contoh puisi yang bertema religi, yaitu puisi yang ditulis oleh Taufik Ismail yang berjudul Ketika Tangan dan Kaki Berkata. Puisi tersebut ditulis setelah membaca Surah Yasin ayat 65 . Berikut puisi bertema religi yang kaya akan nilai-nilai religius.

Ketika Tangan dan Kaki Berkata

\section{Akan datang hari \\ Mulut dikunci \\ Kata tak ada lagi}

Akan tiba masa

Tak ada suara

Dari mulut kita

Berkata tangan kita

Tentang apa yang dilakukannya

Berkata kaki kita

Ke mana saja dia melangkahnya

Tidak tahu kita

Bila harinya

Tanggung jawab, tiba...

Rabbana

Tangan kami

Kaki kami

Mulut kami

Mata hati kami

Luruskanlah

Kukuhkanlah

Di jalan cahaya sempurna

Mohon karunia

Kepada kami

Hamba-Mu

yang hina

Karya kreatif lain selain puisi adalah cerpen. Untuk menginspirasi mahasiswa dapat menulis cerpen religi maka dalam bahan ajar Penulisan Kreatif bermuatan nilainilai karakter religius diberikan beberapa contoh cerpen yang bertema religi. Misalnya cerpen yang ditulis penulis terkenal seperti Asma Nadia dengan cerpen religinya Cinta Laki-Laki Biasa, Rembulan di Mata Ibu, dan Jendela Rara. Selain cerpen yang ditulis Asma Nadia, contoh cerpen yang disajikan untuk menginspirassi mahasiswa yaitu cerpen yang ditulis oleh Habiburrahman El Syirazy seperti $D i$ Atas Sajadah Cinta dan Seratus Peluru untuk Amru.

Pemberian contoh tulisan kreatif yang bertema religius diharapkan dapat menginspirasi 
mahasiswa dalam menulis kreatif. Mereka dapat mengambil tema-tema religi dengan nilai-nilai karakter atau sifat Nabi Muhammad Saw. atau yang bersumber dari Alquran dan hadis. Nilai-nilai karakter religius tersebut dapat diaplikasikan pada judul, isi cerita, karakter tokoh atau pesan moralnya. Dengan demikian, hasil tulisan kreatif mahasiswa kental akan nilai-nilai karakter religius. Harapannya mereka tidak hanya mengaplikasikan nilai-nilai karakter religius pada tulisan mereka, tetapi juga pada kehidupan sehari-hari.

\section{SIMPULAN}

Berdasarkan uraian hasil penelitian dapat ditarik simpulan yang berkaitan dengan bahan ajar Penulis Kreatif yang bermuatan nilainilai pendidikan karakter religius bagi mahasiswa Prodi PBSI, FKIP, Unissula. Adapun simpulan hasil penelitian tersebut sebagai berikut.

1) Kebutuhan terhadap kebutuhan pengembangan bahan ajar Penulis Kreatif yang bermuatan nilai-nilai pendidikan karakter religius mahasiswa mengharapkan bahan ajar tersebut sesuai dengan standar kelayakan buku teks yang meliputi (1) kelayakan isi materi, (2) kelayakan penyajian, (3) kelayakan kebahasaan, dan (4) kelayakan kegrafikaan.

2) Pengembangan bahan ajar Penulisan Kreatif yang bermuatan nilai-nilai pendidikan karakter religius bagi mahasiswa Prodi PBSI, FKIP, Unissula memiliki karakteristik (1) self instructional, (2) self contained, (3) stand alone, (4) adaptive, dan (5) user friendly.

3) Prototipe bahan ajar mata kuliah Penulisan Kreatif bermuatan nilainilai pendidikan karakter religius bagi mahasiswa Prodi Pendidikan Bahasa dan Sastra Indonesia, FKIP, Unissula dengan judul Eksis dan Religius dengan Menulis Kreatif yang berisi cara dan langkah-langkah menulis puisi, cerpen, naskah drama, anekdot, biografi, dan cerita dengan muatan nilai karakter religius.

4) Bahan ajar Penulisan Kreatif yang bermuatan nilai-nilai karakter religius efektif digunakan untuk meningkatkan keterampilan menulis kreatif mahasiswa Prodi PBSI, Unissula.

\section{DAFTAR PUSTAKA}

Azizah, Roisatul. 2011. Implementasi Facebook sebagai Media Menulis Kreatif http://blog.um.ac.id/adekroisa/archives/150 27 April 2012 (Diunduh 12 Desember 2011).

Depdiknas. 2004. Materi Pelatihan Terintegrasi Bahasa Indonesia. Jakarta: Dirjen Dikdasmen.

Depdiknas. 2006b. Pedoman Memilih dan Menyusun Bahan Ajar. Jakarta: Depdiknas. 
Depdiknas. 2008a. Panduan Pengembangan Materi Pembelajaran (http://www.dostoc.com/does/1991556/4_270228) (Diunduh 19 Oktober 2013).

Hidayatullah, M. Furqon. 2010. Pendidikan Karakter: Membangun Peradaban Bangsa. Surakarta: Yuma Pustaka.

Ibrahim, Al-Kaisy Marwan. 2007. Yang Pantas Patut bagi Seorang Muslim. Jakarta: Raja Grafindo.

Pusat Kurikulum dan Perbukuan. 2012. Penilaian Buku Teks Pelajaran. http://puskurbuk.net/web/penilian-buku-teks-pelajaran.html (Diunduh 26 April 2013).

Sugiyono. 2010. Metode Penelitian Pendidikan Pendekatan Kuantitatif, Kualitatif, dan $R \& D$. Bandung: Alfabeta.

Suryaman, Maman. 2008. Mengembangkan Bahan Ajar Bahasa Indonesia. Jogjakarta: UNY.

Tim Pengembang MKDP Kurikulum dan Pembelajaran UPI. 2011. Kurikulum dan Pembelajaran. Bandung: UPI. 